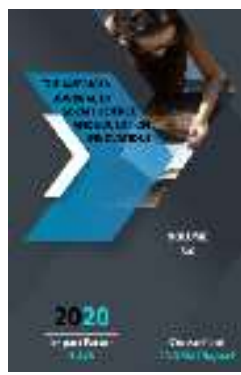

\title{
Methods Of Teaching English To Young Learners
}

\author{
Kuziyev Sarvarbek Ilmiddinovich \\ The English Teacher Of Fergana Polytechnic Institute, Fergana, Uzbekistan
}

Journal Website: http://usajournalshub.c om/index,php/tajssei

Copyright: Original content from this work may be used under the terms of the creative commons attributes 4.0 licence.

\section{ABSTRACT}

This article aims to help young school teachers understand the characteristics of the different methods used in teaching a foreign language to avoid difficulties in teaching a foreign language and to achieve good results taking into account the individual needs of young learners.

\section{KEYWORDS}

Audio-lingualism, Communicative approach, Task-based learning, Humanistic teaching, The Natural Approach, Puppets.

\section{INTRODUCTION}

The most popular methods on which teaching English to $\mathrm{YL}$ is based are the methods listed, for example, by Larsen-Freeman - the Audiolingualism; Presentation-Practice-Production (PPP) and it's alternatives; Communicative approach; Task-based learning; The Four methods: Community Language Learning, The Silent Way, Suggestopedia, Total Physical Response (TPR); Humanistic teaching and the
Lexical approach. However, not all of them are fully used in teaching English to YL [2].

1. Audio-lingualism is based on the behaviourist theory about stimulusresponse - reinforcement in other words about learning new behaviours. In Audio-lingualism it equals engendering good habits in language learning. This form of teaching includes 
mainly drills. The drill is designed to teach a certain form, for example, a correct sentence in Present Simple. Small changes are being performed on the drill so that the students would constantly learn but also to prevent them from making mistakes. The methods have many drawbacks for example it does not allow the student to experiment with the language. On the other hand, it is perfect for $Y L$ for it shows exactly how a proper English sentence should look like and it can be very useful in establishing some fixed sentences and phrases in the student's dictionary [1].

2. Presentation-Practice-Production (PPP) - The PPP method could be characterized as a common-sense approach to teaching as it consists of 3 stages that most people who have learnt how to do anything will be familiar with.

- $\quad$ The first stage is the presentation of an aspect of language in a context that students are familiar with, much the same way that a swimming instructor would demonstrate a stroke outside the pool to beginners.

- $\quad$ The second stage is practice, where students will be given an activity that gives them plenty of opportunities to practice the new aspect of language and become familiar with it whilst receiving limited and appropriate assistance from the teacher. To continue with the analogy, the swimming instructor allowing the children to rehearse the stroke in the pool whilst being close enough to give any support required and plenty of encouragement.

- The final stage is a production where the students will use the language in context, in an activity set up by the teacher who will be giving minimal assistance, like the swimming instructor allowing his young charges to take their first few tentative strokes on their own [3].

3. The Communicative Approach is based on the idea that learning a language successfully comes through having to communicate real meaning. When learners are involved in real communication, their natural strategies for language acquisition will be used, and this will allow them to learn to use the language.

4. Task-Based Learning (TBL) is a lesson structure, a method of sequencing activities in your lessons.

- Sometimes called 'Task-Based Language Teaching', TBL lessons students solve a task that involves an authentic use of language, rather than completing simple language questions about grammar or vocabulary [4].

- $\quad$ Task-Based Learning is a good way to get students engaged and using English. That, plus the collaborative element, builds confidence with language and social situations. It's also been shown to be more aligned with how we learn a language.

5. The lexical approach is a way of analysing and teaching language based on the idea that it is made up of lexical 
units rather than grammatical structures. The units are words, chunks formed by collocations, and fixed phrases.

\section{Total Physical Response (TPR)}

The TPR originator James Asher [5] based his theory on the fact that children learn a foreign language from speech directed to them. TPR is learning from oral instructions given to the students by the teacher. The basic idea is that students are not being made to speak, their main task is to listen to the teacher's instructions in the foreign language and respond to them and only if they feel ready they can start speaking in that language. TPR is a key method to apply when teaching children for it respects the 'silent period' and does not require any previous language knowledge from children.

\section{The Natural Approach}

The Natural Approach is a method that methodologists advice to use at the first stages of teaching to introduce the Total Physical Response. The method concentrates on using the foreign language on the lessons nearly all the time and helping the students understand it by showing them pictures and being as expressive as possible. Listening comprehension is a crucial goal in both TPR and Natural Approach. In fact, it is so important that the teacher does not correct any oral errors made by the students and allows them to use their mother tongue along with the foreign language to communicate on the lesson [6].

\section{Songs}

Songs are a powerful and almost inexhaustible source of English vocabulary. They are a basic teacher's help in teaching in kindergarten based on the Audio-lingual method. Songs are drills but sung. The form of the drill is incorporated into the song and therefore more interesting for children. Songs are even better than typical drills for they are easily remembered and stay in children's minds for long. Usually, each song has choreography for the children to understand the lyrics better and to have more fun singing. Songs, as a technique of teaching, are a very effective way of teaching kids. They teach pronunciation, vocabulary and phrases [3-5].

\section{Chants}

Just like songs chants are another sort of drills. The text of a chant is rhythmical and often rhymed. Chants also can be divided into themes and they sometimes have a simple choreography. The main difference between songs and chants is that chants focus mainly on pronunciation or just 'making' English sounds. The fact that chants are rhymed makes them almost as easy to learn as songs. By remembering chants the students can memorize the lexical items better [4-7]. 
10. Puppets

As it was mentioned before young children have a short attention span so every inventive technique of teaching is welcomed. Puppets are one of such techniques. They are used in stories, songs, chants, role-play and pair work. To teach with the help of puppets, the teacher does not necessarily have to have them made; the other way of teaching with the use of puppets is to make them with the students and teach them such expressions as "draw", "cut", "stick" etc.

\section{Flashcards}

Flashcard's main goal is introducing vocabulary. Working with young learners a teacher must own a huge amount of colourful flashcards concerning all the themes covered in the syllabus. They can be used to introduce vocabulary from the songs before children sing them and in various exercises such as guessing the name of the thing on the flashcard, describing the colour of the thing, as a memo game etc.

\section{Cartoons}

Cartoons can be used at any time during the teaching and training as long as they are relevant to the point or purpose. This specific purpose can be supportive to start a lesson, to keep the learners occupied, alert, and live up the class and to wake them up after a lunch break. Cartoons can be used as a useful source for improving the learning atmosphere. Cartoons are a wonderful and versatile medium in enhancing teaching and training. Visually, the impact of cartoons is immediate and people from all walks of life, irrespective of age or background, are able to respond immediately in the same way to the educational point that is being made. Cartoons can attract attention and interest and it motivates the learners to learn [6-9].

\section{Proverbs}

English proverbs can be used as an alternative to having a lead-in activity. Webster defines a proverb as a short, traditional saying that expresses some obvious truth or similar experiences. Proverbs have been used as teaching tools for centuries to teach moral values and social skills. They may deal with mind, wisdom, experience, learning, and authority. They are indeed effective devices to communicate wisdom and knowledge about human nature and the world at large [10]. Proverbs contain truth in few words that relate to everyday life having a universal value, and they can be remembered easily. Considering the good values of proverbs, a teacher may use proverbs to teach English as a foreign language as a lead-in activity before teaching language skills. It is a good way to consolidate the learning of vocabulary, grammar, sentence patterns, moral values, and the like.

\section{Games}

Games are by far the most joyful of all the techniques already listed. That fact makes them also very effective since the students forget that they are 
learning because they are focusing on having fun and winning the game. In other words, games provide a positive classroom atmosphere and an effective learning environment.

\section{CONCLUSION}

Thus, understanding the main features of foreign language teaching of young schoolchildren with variety of methods discussed above allows the teacher working at the junior level of the school to avoid difficulties arising from learning and to create comfortable conditions for achieving better results, taking into account the individual needs of students.

\section{REFERENCES}

1. Brown, H. D. (2000). Principles of language learning and teaching, (Vol. 4). New York: Longman.

2. Larsen-Freeman, D. (2000). Techniques and principles in language teaching. Oxford University.

3. Crystal, David. (1997). English as a Global Language. Cambridge: Cambridge University Press, Print.

4. Davies, A. (1975). Problems of language and learning. Social Science Research.

5. Asher, J. J. (2000). Year 2000 update for the Total Physical Response, known worldwide as TPR. Los Gatos, CA: Sky Oaks Productions. Retrieved April 22, 2003.

6. Fouts, G., Callan, M., Piasentin, K., \& Lawson, A. (2006). Demonizing in children's television cartoons and Disney animated films. Child psychiatry and human development, 37(1), 15-23.

7. Numonjohnovna, E. N., Ugli, B. B. B., \& Ilmiddinovich, K. S. (2019). Problems in developing speaking skills of students of technical higher educational institutions. Problems of modern science and education, (12-1 (145)).

8. Ergasheva, N. N., \& Kuziev, S. I. (2019). Problems in developing speaking skills of students of technical higher educational institutions. Problems of modern science and education, (12), 95-96.

9. Ismoilova, F. A. (2019). Applying video material in teaching a foreign language. Problems of modern science and education, (12-2), 118-120.

10. Mieder, W. (2004). "Different times, different teachings". Linguistic and cultural-historical considerations on the proverb. 